\title{
ISLAMIC EDUCATION AND LIBERATION FROM FEUDALISM
}

\author{
Syaiful Anwar ${ }^{1}$
}

\begin{abstract}
This article aimed at describing Islamic Education strategies and functions in liberating humankind from feudalism. Islam Believes that everybody's status is equal, one thing that makes him different is his piety. There are Three harmonious relationships can be identified; those are the relationship between human being and God "Allah SWT" (Habblun min Allah, theological aspect), between human being and other human being (Hablun min al-nas, athropo-sociological aspect), and between human being and the natural environment (Hablun min al-'alam, cosmological aspect). These harmonious relationships are the manifestation of perfect faithfulness of a Muslim to Allah SWT.

In the religious dimension, the main purpose of Islam is to develop awareness and understanding about the meaning and of human's life in relation to God. Meanwhile, in terms of social dimension, the purpose of Islamic Education is to develop understanding of harmonious relationship, either between human beings or between human being with the environment. In this context, human beings hold the responsibility for restraining a society from obstinacy, inanity, and anarchism. In this respect, the concept of liberalism in Islamic Education is to place teachers and students in a harmonious relationship. This relationship is to create learning atmosphere which is based on the principle of democratic and two-way relationship.
\end{abstract}

Key words: Islamic Education, feudalism.

\section{Introduction}

The era of global-multidimensional touches every aspect of human being's life: the economy, social, culture, law, politic, technology, and education. Human being's life is a very dynamic. Changes become necessities and Muslim people should always be prepared and open-minded, not to be isolated in a structured feudalism.

Education is a part of basic necessities and also the significant actor of agent of change in the transformation occured. Education is demanded to always be relevant with the continual changes. In the history of Islam, the mission of the coming of the Prophet is not only to teach how to say the name of Allah and how to pray, but what is more important is to liberate human beings from the suffering and the chain that tie human liberation.

${ }^{1}$ Dr. Syaiful Anwar, M.Pd, lecturer of Islamic Education in and the Dean of the Faculty of Tarbiyah IAIN Raden Intan Lampung. This article has been reviewed by Prof. Susanto Zuhdi, Universitas Indonesia), and Prof. Dr. Qasim Ahmad (Universiti Teknologi Mara, Malaysia) 
By following the khittah of the Prophet, a Muslim has the responsibility to continue the job of the Prophet in his society, to bring the society into light, prosperity, peace, and happiness. Therefore, a Muslim's piety to Allah in administering religious service of mahdhah is not yet perfect until he can manifest the moral message in the religious service at the social level. In other words, one's social piety is the substance of the faithfulness.

It can be manifested by Islamic education, which holds strategic roles to liberate human beings from feudalism and support the regulation framework and empower those Muslim to be a mankind whom are capable of conducting the rahmatan lil'alamin mission. Therefore, the administration of education must respect humanistic values. Thus, humanistic Islamic education is aimed to shapen a human being to be a human with awareness, freedom, and responsibility.

However, what about the relation between Islamic education in liberating Muslim people from feudalism and the establishment of humanistic?, is'it just developing, civilized egalitarian, democratic, and humanistic civilization so that it can be a frame of reference in regulating human conducts? This article presents a writing related to the issue and invites discourse and discussions for the more progressive and constructive knowledge.

\section{Islamic Education and Feudalism}

Being faithful to Allah SWT is human beings' nature since they were born; later on, they will bear this faith. Nurcholis Madjid says that human beings, according to how they were created, are pure and kind. Therefore they already bear purity and wisdom with them (Nurcholis Madjid, 1992: 305). Meanwhile, Sayid Sabiz's terms of fitrah as Gharizah Diniyah, which is a feeling attached to humans' hearts and humans' souls that can feel the existence of God (Sayid Sabiq, 1982: 73). Gharizah sometimes is closed or lost, whether in part or as a whole due to, one of them, is the lack of education or guidance to keep on fitrah.

Islam is the religion which highly supports and maintains education. In $\mathrm{Al}-$ Qur'an there are so many verses concerning this matter. Even the first apocalypse, which is "iqra' bismi rabbika 'l-ladzi khalaq', given to the Prophet of Muhammad is merely about education and learning. The verses contain a command, that Allah also ask the prophet Muhammad, to read a lot. This reading can be defined as teaching and learning activities.

Etymologically, Islamic Education is taken from three Arabic terms, "tarbiyah", "ta'lim", and "ta'dib”. In general, Islamic experts often translate it into at-Tarbiyah al-Islamiyah. To explain the term "tarbiyah", they refer to the terms in al-Qur'an such as "rabb" (al-Fatihah: 2), "rabbyani" (Bani Israil: 24), "raba-yarbu” (Ar-Rum: 39), "rabiyah" (al-Haqqah: 10), "murabbi” (al-fatihah: 2), "rabbiyyin dan ribbiyani" (ali-Imran: 146).

Yusuf al-Qardhawiy argues that Islamic education is a truly human education: the brain and the mind, the spirit and the body, and the morality and 
the skill (Yusuf al-Qardhawiy, 1980: 39). According to Muhammad 'Athiyah alAbrasyiy, Islamic Education is akhlaq (morality) education; nevertheless, it does not ignore one's preparation to get a job and to earn for one's living; this is so since the education involves physical, mind, skills, language, and other education (Muhammad 'Athiyah al-Abrasyiy, 1975: 3). Ahmad Fu'ad al-Ahwaniy argues that Islamic education since the borne of Islam has been religious education, morality, conduct, and physical education. This is because Islamic education is aimed to teach and clean someones soul, sharfen that his mind and streng then his body (Ahmad Fu'ad al-Ahwaniy, t.t.: 9). On the other brand, H. M. Arifin has the opinion that Islamic education is a system of education which deserves someone some appropriate skills in accordance with Islam's desire, because in his or her soul and personality has been planted by Islamic values (H. M. Arifin, 1996: 10).

Islamic education objective, according to Hasan Langgulung, is to create faithful and morally good human being. (Hasan Langgulung, 1985: 137). According to Muhammad 'Athiyah, al-Abrasyiy is the achievement of perfect morality. (Muhammad 'Athiyah al-Abrashyiy, 1975: 22). Abdurrahman Saleh relates the goal of Islamic education into three basic components of human beings, which are body, soul, and mind, to be physical goal (ahdaf al-jismiyyah), spiritual goal (ahdaf ar-ruhiyyah), and mind goal (ahdaf al-'aqliyyah). The writer then concludes that the purpose of Islamic education is to create a perfect human being in terms of spiritual and physical aspects to be able to live at his best both in the world and in the hereafter in accordance with the nature of his creation, which is to devote himself to Allah SWT.

Muhammad Munir Marsiy explains that the roles of Islamic education in reaching the goals of humans' life are:

a. Islamic education is a perfect education,

b. Islamic education is a balanced education,

c. Islamic education is theory and practice education,

d. Islamic education is individual and social,

e. Islamic education is conscientious education and is in accordance with the nature of human beings,

f. Islamic education is education oriented towards wistful wisdom,

g. Islamic education is continual education, and

h. Islamic education is universal humanistic education (Muhammad Munir Marsiy, t.t.: 21-31).

On the other hand, feudalism is a Europe term in the middle ages, around 1748, with its main figure, Montesquieu's masterwork De L'Esprit des Lois (The Spirit of the Laws). Feudalism becomes a term frequently used to show an understanding of the existence of a strong gap between the authorities and the people, where there is usually a social system with leveling or castes. In a society which follows feudalism, it is frequent that human's freedom become limited and oppression occurs between the strong towards the weak. Respect for others is 
measured from authority aspect, economic ability, and social status. Slavery is one of the examples of feudalism; in addition, poverty, stupidity, discrimination, injustice, and oppression also frequently happen.

In English, the term feudalism is used to refer to the aristocracy or a kingdom in England in the golden era of the country where the country became the world's imperialist and a superpower kingdom. In Latin, the term feudalism is "feodum" which means "land". The characteristics of feudal society are as follows:

1. Characterized by higher level society, which is Lord (Landlord) and vassal (labors).

2. The control (of all aspects) by the higher level society to the lower level one.

3. Absolute submission of the lower level to the higher level society.

4. The life of the lower level people is determined by the higher level people.

5. The power and authority are only owned by the higher level society.

6. The lower level society does not have the right to give opinion.

7. The higher level society gives physical and psychological protection for the lower level society as a consequence and or a return of the lower level society who has devoted to the higher level society.

8. The social leveling is not enclosed.

9. It is a shift from slavery to laborship.

10. It is difficult for the lower level society to climb to be higher level society.

Meanwhile in Japan, the basis for the birth of feudalistic governmental system started since the military government in Japan, which is Kamakura period. The significant characteristic of the political system in that ear was the dichotomy of authority, that is civil government and religion centered in the Tennou Palace in Kyouto had a very small portion of a power compared to the military government which was established by Yoritomo in Kamakura. This political system was continued running for almost 700 years until the era of Tokugawa. The aim of the government to implement the feudalistic system was, one of them, to press the lower level rebellion such as the Gekokujo.

Whereas in Indonesia, feudalistic system shows caste leveling which was formed among the Javanese, which were the noblemen, Islamic education students, and the non-followers of religion. The people from the aristocracy or noblemen were called the "blue-blood" people with their unique characteristic and attitude of feudal. This segmentation is prevalent, which means that the noblemen will continually and from generation to the next generation occupy the position of higher class while the lower level society will forever be in the lower level.

The influence of the feudalistic system spread in all aspects of life: economy, social, culture, law, politic, technology, and education. In the field of education, the hierarchy of the educational institute tended to preserve feudalism, growing aristocracy than democracy. In the learning process, teachers occupied more sacred position, without any mistake, and know everything; while students only listened to and obeyed what were instructed. 
However, in this era of reformation, the influence of feudalism slowly faded. Every person has the same opportunity to raise his or her stats and dignity and to not be treated as a weak person. The most important thing in the spirit of reformation is that all humans are born to be similar and without any caste. Every human being has the same level. Oppression and civil rights arrogation are violations for the equality among human beings, what so over in front of God. The growth of feudalism only gives birth to disintegration, conflicts, and riots, and the establishment of authoritarian system. As a sovereign country which follows democratic system, of course, feudalism will never develop here. Feudalism is in opposition with independence, freedom, and principle human rights.

\section{The Constellation of Islamic Education and Feudalism}

Education is the facility and medium in an attempt of optimizing and actualizing the humanistic potential of human beings. Categorically, A-Qur'an positions human beings in two basic functions. First, as 'abdullah (Allah's servant); secondly, as khalifatul fil ardhi (Allah's representative on earth). A complete person should perform two wisdoms: knowledge wisdom and social wisdom.

From the obligation, the foundation of Islamic Education is based and also orienting human beings towards three functional relationship patterns; they are relationship between human being and God "Allah SWT" (Habblun min Allah, theological aspect), between human being and other human being (Hablun min al-nas, anthropo-sociological aspect), and between human being and the natural environment (hablun min al-'alam, cosmological aspect).

In the religious dimension, Islamic education orients towards the growth of awareness and the development of understandings on the origin and the goal of human's life in relation to Allah. On the other hand, in the social dimension, Islamic education is oriented towards the development of understanding to maintain harmonious relationship between human beings and between human beings and their environment. From the above context, human beings are obliged to strive to keep the society away from obstinacy, anarchism, and status quo with all of their abilities (knowledge, skills, morality, and personality). Only through education that human beings can gain these abilities in line with what Islam has commanded.

From the anthropological-Islamic religious point of view, human beings are created by Allah SWT in their most perfect form. In Al-Qur'an Allah SWT says:

"We have indeed created man in the best of moulds." (At-Tin: 4).

Human beings are also more noble than other beings. It is said by Allah SWT:

"We have honored the sons of Adam; provided them with transport on land and sea; given them for sustenance things good and pure; and 
conferred on them special favors, above a great part of Our Creation."

(Al-Israa: 70).

Therefore, in Al-Qur'anul Karim, human beings as ones created by Allah SWT in the world are given duties and responsibilities to:

1. Human beings are the servants for Allah the Creator

Say: "Call on those - besides Him - whom ye fancy: they have neither the power to remove your troubles from you nor to change them." (Adz-Dzariyat: 56)

The verse above explicitly explains that human beings and genies are created to devote their lives to Allah. The word ya'budun is the fi't form of mudhari' and fi'il madhiy' abada which is rooted from the word 'ain, ba' and dal which mean weakness and abjection.

Loyalty is the confession to rubbubiyah (Allah as the Creator and the Caretaker). However, if the loyalty is in the form of hoping for help from Allah in every misery, it is not appropriate without being balanced with self devotion, faithfulness, and obedience which is the uluhiyah right (the right of Allah to be worshipped, followed, and obeyed) as said in Al-Qur'an:

Thee do we worship, and Thine aid we seek. (Al-fatihah: 5).

The principle of obedience to Allah is to be aware of His being the only One and his power which involves the whole nature, because all of it is His creation. The more knowledge human beings have about their Rabb and the more aware human beings of their weakness, the stronger their feelings to rely on Allah by trusting God, asking for His help, lowering themselves, and kneeling in front of Him and praying to receive His willingness and his forgiveness.

2. Human beings as the leaders on earth

Al-Qur'an has explained the duty of human beings as the leaders on earth.

Behold thy Lord said to the angels: "I will create a vicegerent on earth." They said "Wilt thou place therein one who will make mischief therein and shed blood? Whilst we do celebrate Thy praises and glorify Thy holy (name)?” He said: "I know what ye know not."

The word khalifah in Al-Qur'an is found twice in the form of mufrad and four times in the plural form of (khala'if) and three times in the plural form (Khulafa) (Muhammad Fu'ad 'Abd. Albaqiy, t.t.: 240); and in the form of mufradat (khalif). etimologically, the word is rooted from the letter $k h a$ ', lam, and $\mathrm{fa}$, which have three meanings "to replace, behind, and change". in this context, the meaning of khalifah is more appropriate as substitute, where human beings are substitutes of Allah as khalifah on earth, in accordance with the message and command from Allah SWT.

3. Human beings as the actors who develop and bring prosperity on earth Allah SWT has described the duty in Hud: 61 as follow: 
To the Thamud People (We sent) Salih, one of their own brethren. He said: "O my people! worship Allah: ye have no other God but Him. It is He Who hath produced you from the earth and settled you therein: then ask forgiveness of Him, and turn to Him (in repentance): for my Lord is (always) near, ready to answer." (Hud: 61)

Allah SWT's word above was the basic duty of human beings to develop and bring prosperity on earth as mentioned by the phrase wasta'marakumfiha. the verb ista'mara comes from the root word with the letters of 'ain, mim, and ra' which means eternity and a long era; something high or increasing, or in 'imarat al-ardh relationship (bring prosperity on earth) (Ibn Faris: 140: 141). It means the command to take care of the earth so that humans' prosperity can be achieved.

Seen from Islamic anthropologic-social aspect, human beings are obliged to maintain the ihablun min al-nas relationship, that is to maintain understanding between human beings. The first principle that becomes the basis for maintain good relationship between human beings is the tauhid point of view that humans beings are equal (al-Baqarah: 213) in a diversity/plurality.

O mankind! We created you from a single (pair) of a male and a female, and made you into nations and tribes, that ye may know each other (not that ye may despise each other). Verily the most honored of you in the sight of Allah is (he who is) the most righteous of you. And Allah has full knowledge and is well acquainted (with all things). (Al-Hujurat: 13)

This verse acknowledges the fact that existentially there are differences among human beings. However, whatever differences they are whether skin color, race, gender, ethnic, nation, language, or religion are not something to oppose; instead, the differences should be the reason to know each other (lita'arafu) as a teaching learning process of understanding, getting acquainted, knowing the characters, personalities and acknowledging the rights and obligation.

Collective life, according to Al-Qur'an is not a vehicle to oppress the weak, lower others' dignity, but to strengthen the dignity of human beings. therefore, Islam assertively prohibits hierarchical/monarchy relationship among people because it will bear negative effects such as authoritarian people and ignore conscience sensitivity, result in tyranny, oppression, abuse, discrimination, and other human rights violation.

In relation to that, Paulo Friere, an expert of education from Brazil who is called as multicontinental figure has succeeded in observing such education phenomenon as the target of his critiques in his famous work of "Education of the Oppressed". According to Fierre, education makes the oppressed people become the object of humanitarianism. Educational activities frequently become saving activity. Teachers deliver knowledge and students obediently receive it without active and critical process. The students are saving box and teachers as the 
depositors. In this education pattern, individual creativity and progressiveness become chained.

In that kind of banking style education, education is to transfer certain knowledge from teachers to their students. Education should be more than just a transfer of knowledge. It should be born in mind that to educate has more intensified meaning that to teach. Education is a process of transferring, planting, and shaping knowledge, skill, values/norms, so that students will grow as knowledgeable, skilled children with good morality. Meanwhile, teaching is defined as the transfer of knowledge to students without paying to attention on whether students understand, become skilled, or have good personalities.

In such educational practices, teachers actually have become oppressors and students become the oppressed. Therefore, Islamic education is expected to reposition the distorted value of humanistic by reconstructing the concept of Islamic education departing from and oriented to the more systematic and realistic development of human beings' nature.

\section{The True Goal of Non-Feudalistic Education: Bring Human Beings into Kaffah faithfulness in God}

Etymologically, the word tauhid comes from the words wahhadayuwahuddu-tauhidan which means, one, singularity, or to believe in one. Tauhid literally means believe in one or think of one; while in broader meaning it refers to a belief or trust which only acknowledges one God, which is Allah SWT. In this regards, it can be called as monotheism.

Tauhid means to be committed, submissive, and loyal only to Allah SWT as a whole and comprehensively (Kaffah). Al-Qur'an as the guidance for human beings is a holy book that guides human beings to be faithful and to believe in Allah SWT. there are many stories of prophets and apostles in Al-Qur'an which can be made as good examples, more specifically, Al-Qur'an shows the figure of Luqman Hakim as the pedagogic actor who has succeeded in teaching tauhid education. Allah SWT says

Behold, Luqman said to his son admonishing him: "O my son! Join not in worship (others) with Allah: for false worship is indeed the highest wrong-doing." (Luqman: 13)

From the story of Luqman some lessons can be taken: first, that the first and the most important education for children is tauhid education; that is growing faithfulness to Allah SWT correctly. Secondly, the educative content is in the form of human beings' faithfulness dimension actualization. Such belief contains meaning that a faithful person does not say or feel anything other than to describe his faithfulness to Allah SWT.

In feudalistic society, devotion or worship in general is given by the lower level society to the authorities, but in Islam, only Allah SWT that deserves to 
be worshipped, to not believe in another God or anything else to worship. In worshipping Allah, Allah deserves to receive more affection than any other thing in the world, when one loves something or someone more than his or her love to Allah then it is considered as violating the nature of humans' creation as explained in the following verse:

I have only created jins and men, that they may serve Me. (Adz-Dzariyat: 56)

The verse above explicitly explains that human beings and gennies are created to serve Allah. The word ' $a b d$ with the form of isim in Al-Qur'an was firstly invented in the order of the coming of al-'Alaq: 10; in the form of fi'il mudhari in al-Fatihah: 5. In this regard, as has been a common knowledge that al-'Alaq was the first verses given by Allah SWT to the Prophet Muhammad SAW and alFatihah is Ummul Qur'an. This shows that the main content of al-Qur'an is about the believe in Allah the only God.

Tauhid/Akidah in Islam involves the belief in Allah as the God to worship; oral statements in the form of two syahadat sentences. Such akidah contains the meaning that a faithful person will not say or act but as a whole to represent his faithfulness to Allah SWT.

In Islam, someone who wish to convert to Muslim is required to read the syahadat "Asyhadu an la'ilaha illa-Allah wa asyhadu anna Muhammad Rasullah". A short sentence but is very essential for the life of a Muslim. According to Muhammad Said al-Qothani (1994: 30), the sentence of La 'ilaha illa-Allah covers some meanings:

a. Only Allah that deserves to be worshipped.

b. the absolute law comes from Him

c. no absolute authority other than Allah, He is the Rabb of the nature, the authority and the controller

d. no creator but Him

e. nothing can give fortune but $\mathrm{He}$

f. no Illah who gives life and who takes the life but Allah

g. nothing can give wisdom and benefit but Allah

h. no other power but He.

Submissiveness and loyalty without reserve to Allah is really needed for human beings to strengthen their belief and center their devotion to the only one authority who has every power. Therefore, tauhid sentences must be defined in the three following perspectives:

1. Tauhid gives birth to the confession that there is only one God who creates, maintains everything, and protects the world. Because of that, any kind of "musyrik" activities (believe in God other than Allah) is not accepted and is very opposing to tauhid concept .

2. God has every trait which is not owned by anything other than Him. 
3. Tauhid orients human beings to clear life goals. In this perspective, understanding of the tauhid sentences brings human beings to more comprehend rubbubiyah Allah, his uluhiyah, and tauhidullah in his traits.

Rububiyah Allah is to put Allah as the only creator of everything that exists. He is the authority and the controller of all the mechanism and deeds of his creations. Rubbubiyah Allah also contains the meaning that Allah is the absolute actor of every event, such as creation process, control, transformation, determination, the giving of life, and the taking of life (al-Qothani, 1994: 1-5).

To believe in rubbubiyah Allah must be accompanied by believing in His uluhiyah. Uluhiyah Allah is an affirmation of His servant that ilahul haq, no God but Allah. With Uluhiyah tauhid, human beings' goal of life becomes clearer. Human beings do not have to be submissive and to devote to anything and anybody, but only to Allah (Raharjo, 1993: 437).

By looking at the meaning of La'ilaha illa-Allah it can be understood that the whole orientation of the life of a Muslim is Allah. However, the true wit in Islam does not merely in words and in the confession of his heart; but also it must be accompanied by practicing the belief with kaffah along with all of its rules, both spiritually and physically. With lailaha illa-Allah, a Muslim does not only eliminate what to be worshipped but Allah, but also determine that Allah is the only one to worship. The syahadat sentences show loyalty and self-cleanliness (al wala' wa al barra') and its negation and affirmation (al nafy wa al-itsbat).

The concept of al wala' in the syahadat sentence is an aspect of willing submissiveness and loyalty to Allah, His holy book, his sunnah, and His Prophets; whereas, al barra'means self-cleanliness from all of taghut's control and jahilliyah laws. As for al nafy, it means eliminating something that competes the belief in the only God but Allah, such as mediator to worship Allah, a master, and thagut. In al-itsbat, there are four issues: final destination, love, fear, and hoping to Allah (al-Qothany, 1994: 6-8).

Through al nafy, someone starts liberalization process, to be liberated from the chain of believing fake things. However, for the sake of human beings' perfect life, human beings must have beliefs in something true. Life without any trust is impossible. Here, affirmation is needed, to merely acknowledge that God truely deserves to receive center of attention and total (kaffah) devotion.

With this kind of understanding, al wala'wa al barra' is a must from La'ilaha illa-Allah and also the manifestation of the meaning of the sentence. Like what is said by Syaikh al-Islam Ibn Taimiyah "The manifestation of the testimony of La'ilaha illa-Allah demands someone to not love something because of Allah, to not hate but because of Allah, to not be loyal but because of Allah, to not condemn but because of Allah, to love what Allah loves and to hate what Allah hates."

Islamic theology, in line with the tauhid principle, does not recognize and even deny any mediator of worshipping. This is so since al-Qur'an has said that 
Allah is so close to human beings. Because of His closeness to human beings, actually human beings do not have any difficulties to stay in contact with God. Every activity conducted by human beings will not be separated from the control and involvement of Allah. In this regards, Allah says:

When My servants ask thee concerning Me, I am indeed close (to them); I listen to the prayer of every suppliant when he calleth on Me; let them also with a will listen to My call and believe in Me; that they may walk in the right way. (Al-Baqarah: 186).

From the explanatin above, this principle becomes the main essential aim of non-feudalistic education; that is to bring human beings to the belief of Allah as the only God which is Kaffah. The tauhid dimension is a study and also the main goal of Islamic Education. The Prophet Muhammad SAW was sent to spread this mission of tauhid. Sayyid Muhammad Husayni Baheshti (Sayyid Muhammad Husayni Baheshti, 2002: 42) proposes two conclusions of two experts in interpreting concerning the mission of belief in one God brought by the Prophets and Apostles, which are:

1. As interpreting expert, he argues that the mission of the Prophets and Apostles is to spread the news on the existence of God. Related to that, Allah says:

And yet among men there are such as dispute about Allah, without knowledge, and follow every evil one obstinate in rebellion! (Al-Hajj: 3)

2. Other experts argue that the prophets and apostles were sent with the mission of spearing the belief in only one God or to eliminate "musyrik". Related to this, Allah says:

Do ye not see that Allah has subjected to your (use) all things in the heavens and on earth, and has made His bounties flow to you in exceeding measure, (both) seen and unseen? Yet there are among men those who dispute about Allah without knowledge and without guidance, and without a Book to enlighten them! (Luqman: 20)

From these perspectives, some formulation of tauhid-based education can be taken, such as the following:

a. Committed to be submissive and loyal to Allah SWT. Trying hard to conduct what is commanded and stay away from what is prohibited by God.

b. Denying all concepts and point of view which do not come from Allah. In this context it means that emancipation and restoration of liberation of all chains that limit human beings.

c. Be progressive and always bring about transformation on the life quality, customs, tradition, and deviate from the concept of life that is oriented towards syirik activities or which is not in accordance with Allah's rules.

d. Not being tempted by worldly values or attributes which are not the main goals. The main goal is to merely for and in the name of Allah and to look for His willingness,

e. Having the vision and mission of a social life which is just, peaceful, prosperous, 
democratic, egalitarian, and humanistic; respecting human rights and maintaining harmonious relationship both horizontally and vertically (Haidar Ali Ahmad, 2005: 12-13).

Faith in Islam must give influence to all human's activities, so that various activities will be valuable in front of God. In this relation, Yusuf al-Qardawi says that according to its definition, faithfulness is actually the belief which penetrates into heart with high trust, without any hesitation, and gives influence towards life's point of view, attitude, and daily activities (Yusuf al-Qardawi, 1977: 25). It can be said that tauhid becomes the basis for the establishment of moral and religious human civilization.

Nevertheless, the understanding of tauhid concept does not stop at the act of only believing Allah as the only God but also by believing the unity of creation, wahdat al-khaliq al-mudabbir, unity of mankind wahdat al-insaniyat, unity of guidance of life wahdat al-masdar al hayat, and unity of purpose of life, wahdat nihayat al-hayat which are all derivative from unity of God as the only one, wahdaniyat (Quthb in Amin rais, 1989: 18).

Further consequence of the internalization of tauhid is the denial of human's dependency on certain social power in any of its forms, and in reverse, and in return, human beings will receive blessing and liberality from Allah. By being submissive only to Allah makes human beings be in opposition with all kinds of evil things and social deviances, liberating themselves from any chain. In short, tauhid is a form of human beings' radical liberalization towards anything other than God. Thus, education as viewed by tauhid is education based on the principles of ilahiyah values (theology), ubudiyah, and insaniah (anthroposocialist).

The meaning of Kaffah here, in terms of religious understanding, has to be comprehensive and in a whole for a religious teaching; an understanding that a religion is an absolute truth but is not imposed on other people. In building religious relationship, human beings should be able not only to hold the true religious values, but also able to cooperate with other followers of different religion tolerantly and harmoniously without violating the faithfulness lesson. In this regards, it is called inclusive understanding of religion.

\section{Humanistic Reflection: The Liberating Islamic Education}

In essence, human beings are pedagogic beings; which means that they are able to be educated and to educate. Therefore, human beings are also often called homo educandum; that is beings that are able to be knowledgeable, to think, and develop the knowledge. In Islam, human beings have the same significant position. They are so significant that Al-Qur'an repeatedly says about human being more than 60 times (insan) (M. Dawam Rahardjo, 1985: 29). Abul A'la Al Maududi in his great work of "The Meaning of the Al-Qur'an" says that the main topic of 
Al'Q-ur'an is about human beings. Maududi also says in "The Basic Principles of Understanding Al-Qur'an" that the central theme of Qur'an discussion is the human beings themselves (M. Dawam rahardjo, 1985: 212).

The nature of human beings in education (the man's ontological vocationthe terms given by Paulo Fierre) is to be the actor with creativity and ability to create, without oppressiveness, and able to give space for movements for humanistic actualization. All human beings are independent, in the essence that they are able to develop wholly and in harmonious with all of their humanistic aspects. Thus, Ki Hajar Dewantara proposes a saying "educate the head, the heart, and the hand".

In relation to that, liberating Islamic Education is a concept of education expressing human beings as Allah's servants who have to be liberated from all kinds of slavery, but only slavery to Allah SWT. Therefore, educational practices orienting towards feudalism cannot be maintained because they are in opposition with the humanistic values which position and respect human's dignity.

In addition, feudalism in education is also not appropriate with the reality of contemporary knowledge development. This is in line with how Alfred North Whitehad, a physolopher, defines teaching as a process of transferring the no longer relevant knowledge for the present life or for the future. Therefore, liberation in education through education humanization is a must in the current human beings' civilization.

In the pragmatic level, feudalism in education has its root of, one of them, the Science mechanistic paradigm domination of Cartesian Newtonian which makes human beings like "robots" chained with the development conducted by the authority. The principle of cogito ergo sum which comes from Cartesian ecology tradition is as if more as concept thinker, policy maker, and educational practitioner who position students as the object and teachers as the knowledge giver. From this point, subject-object relation in the world of education is created. In Freire's language, the relation can be called as oppressive relation. Human beings as subject is a knowing-all-being, while humans as object is stupid and is an empty tube not knowing anything.

Therefore, humanistic Islamic Education (at-tarbiyah al-islamiyat) means to educate according the potentials or to grow the potentials according to human nature. In essence, Islamic Education is rabbaniy as is mentioned in Ali 'Imran 79:

It is not (possible) that a man to whom is given the Book, and Wisdom, and the prophetic, office should say to people: "Be ye my worshippers rather than Allah's; on the contrary (he would say): "Be ye worshippers of Him (Who is truly the Cherisher of all) for ye have taught the Book and ye have studied it earnestly." (Ali “Imran: 79)

What is meant by Rabbaniy is a person who is perfect in terms of his or her knowledge and his or her faithfulness to Allah SWT, in which some of the 
characters are teaching the Holy Book, whether written or not in Al-Qur'an, and continually learning it. (M. Quraish Shihab, 1992: 177-178).

In practice, the concept of liberating Islamic Education positions teachers and students in a harmonious relationship by creating learning atmosphere based on the principle of democratic dialogue, without creating an image of students as objects, passive, stupid, and the like. To achieve that kind of awareness, Islamic Education which only emphasizes verbal, cognitive, and ritual-minded teaching material cannot be maintained and should be replaced by practical Islamic religious activities which require experience, practice, and total comprehension of the true meanings.

Based on the point of view, liberating Islamic Education formulates that the purpose of learning is to support or help students to learn and actualize themselves. Students, who are naturally active and creative, process to shape and manifest themselves with their own ability and desire. The role of teachers is only to help them be aware of their own potentials by creating conducive teachinglearning atmosphere.

Ideally, students are trained and conditioned to search themselves all kinds of knowledge with their own thoughts. Therefore, students will feel that their existence is acknowledged. The education process which ignores the existence of students as human beings violates freedom and humanistic values. Such education is what Paulo Friere calls as The Banking Concept of Education.

Below are the characteristics of liberating education:

a. Teachers are to teach, students are to study.

b. Teachers know all, students do not know anything.

c. Teachers always think, students are never thought of.

d. Teachers tell stories, students obediently listen ot them.

e. Teachers decide rules, students are to be ruled.

f. Teachers select and impose their choice, students agree on them.

g. Teachers act, students imagine themselves through the act of their teachers.

$\mathrm{h}$. Teachers select teaching material and content, students (without being asked of their opinion) adapt to the material.

i. Teachers mix knowledge and their authority to limit students' freedom.

j. Teachers are subjects in the learning process, students are merely objects.

(Paulo Friere, 1995: 51-52)

As mentioned above, in each interaction occurred, students must be respected for their existence. Basically, students want to exist physically and psychologically. In regards with motivation, students need to be given freedom and looseness appropriate with their individual differences. Individual humanism, with its figures such as Petrarch (1304-1374), Boccacio (1313-1375), and Vittorino De Feltre (1378-1446), argue that the purpose of education is liberal thinking, developing individual personality, and expressing oneself according to one's talent and interest. (Sumadi Suryabrata, 1990: 12) 
Nevertheless, the referred freedom is the positive-constructivist freedom with a dimension of educative values. Students are given freedom to search for and develop their knowledge. Giving freedom can grow discipline that manifests in individual, not just artificial discipline that is resulted from external influence because of the fear of various rules and sanctions.

Teachers are more of as guides or helpers instead of the main determiner of the success of learning. In this regards, teaching is based on the principle of learning by doing. In other words, both teachers and students need to humanize each other. In the process, teachers can propose teaching material that has been considered based on the needs analysis, whether directly or indirectly, so that an inter-subject two-way interaction to understand an object together can be created.

In terms of the teaching method of Islamic Education, it is suggested that the relationship between teachers and students is a two-way and communicative relationship. Teachers are not viewed as the only learning resources; the same way is true for students: they are not merely object of teaching. On the other hand, teachers and students are learning subjects so that the learning atmosphere in the classroom will no longer be dynamic and alive. In this context, students are more active. Students no longer sit down only and listen to teachers' explanation, but actively involve physically and psychologically, and involve all of their senses to achieve maximum understanding. Here, the teaching method developed by Paulo Freire is defined as human empowerment to be independent and creative.

The argument of M. Nasir Budiman on the educational strategies of Qur'ani morale, covers tadzakkur, tadabbur, tafaqquh, and tafakkur (M. Nasir Budiman, 1960: 44). Tadzakkur is to invite students to say the name of Allah whenever and wherever. Tadabbur is to invite students to exploit their potentials by reflecting on Allah's verses either in the manner of qauliyah or Kauniyah. Tafaqquh is to invite students to understand and take the lesson from Allah's sayings so that Qur'ani moral among students can be created. Tafakkur is to invite students to use their potentials to think in order to comprehend both qauliyah and kauniyah verses as their object of study so that children are able to find moral values contained in the verses of Qur'an.

Islam shows the significance of a method to reach a goal. Therefore, in Islam, Islamic Education Methodology can be found. The principles of Islamic Education are as follows:

a. The principle of giving a nuance of happiness

This principle reflects that Allah wishes for easiness, not the reversal. Allah SWT says:

Allah intends every facility for you He does not want to put you to difficulties. (He wants you) to complete the prescribed period, and to glorify Him in that He has guided you; and perchance ye shall be grateful. (Al-Baqara: 185) 
Allah also commands to give happiness for faithful people and to do goodness (Al-Baqara: 25 is one of the examples of this command).

b. The principle of providing services and helps gently

In administering education, teachers ideally give services gently and respectfully. To borrow the terminology of Ki Hajar Dewantara, "we are slaves for our students". In regard with this, Al-Qur'an explains this in Ali Imran: 159.

c. The principle of meaningfulness for students

This principle departs from the psychological analysis that education is ideally given according to the level of students' age development. Related to this, Rasulullah says:

"Talk to human beings according to their abilities"

d. The principle of pre-requisites

This principle means to attract students' interest/attention on the teaching material being learned. In Al-Qur'an, there are many methods (manhaj) in which Allah gives pre-requisites to human beings to attract their attention. Many verses contain tanbih (asking for attention) such as the words Alif Lam Mim, Kaf Ha Ya 'Ain Shad, Ya Sin, Ha Mim, etc.

e. The principle of open communication

In the holy book of Qur'an, there is Allah's saying which pushes human beings to open their hearts and minds, and feelings, hearing, and sight to understand the messages given by Allah SWT. Look at Allah's verse in Al'Araf: 179 .

f. The principle of a good model

An educator needs to be uswah hasanah for their students, just like Rasulullah, as an educator who is always uswah hasanah for his best friends as his students. In regards with this, see Al-Ahzab: 21.

It becomes clear that the expected result of Islamic education is the birth of graduates who have the characteristics of ulu albab; that is someone who is always tadabbur, 'itibar, wise, and faithful. Ulul Albab is someone who can integrate the two intellectual potentials (in thought) and spiritually. Therefore, in relation to Islamic education liberating feudalism, it functions to trans-formulate the values and to make students have good personalities and be committed to the maintenance of truth and justice in the path of Allah SWT and to merely hope for His willingness.

\section{Conclusion}

Islam teaches to position human beings as egalitarian and rejects any form of oppression. Islamic Education has the strategic plans of liberating human beings from feudalism. To build the three relationship patterns which are functional, correlational, and harmonious between human beings and Allah (hablun min Allah, theological aspect), between human beings and human beings (hablun 
min al-nas, anthropo-sociological aspect), and between human beings and the environment (hablun min al-'alam, cosmological aspect) is the manifestation of a Muslim' faithfulness to Allah in conducting mahdhah religious service.

From the dimension of religion, Islamic Education is oriented to grow awareness and to develop understanding on the origins and goals of human beings with their relation to Allah. On the other hand, from the social dimension, Islamic education is oriented to develop understanding in maintaining harmonious relationship both between human beings and human beings and between human beings and their surroundings. From the above context, human beings are responsible to strive to stay away from obstinacy, inanity, and anarchism with all of their abilities (knowledge, skill, morale, and personality).

In practice, the concept of liberating Islamic Education positions teachers and students in a harmonious relationship by creating a democratic and two-way relationship, where the purpose of education is as an attempt of mentoring or guiding students to study and to actualize themselves. In this regards, teaching implements the learning by doing principle.

\section{REFERENCES}

'Abd.Al-Baqiy. (t.t). Muhammad Fu'ad. Al-Mu’jam li Alfazh Al-Qur'an al-Karim. [t.t]: Dar al-Sya'b,

Ahmad, H. A. (2005). Pendidikan Agama dan Keagamaan. Jakarta: Balai penelitian dan pengembangan agama.

al-Abrasyiy, M. 'A. (1975). At-Tarbiyah al-Islamiyah wa Falasifatuha (Mishr: 'Isa al-Babiy al-Halabiy).

al-Ahwaniy, A.F . (t.t.). At-Tarbiyah fil Islam. Kairo: Dar al-Ma'arif.

al-Qardhawiy, Y. (1977). Iman dan kehidupan, (terj.) H. Fachruddin Hs., dari judul Al-Iman wa Al-Hayat. Jakarta: Bulan Bintang.

al-Qardhawiy, Y. (1980). At-Tarbiyah al-Islamiyah wa Madrasah Hasan alBanna. Penerjemah:H. Bustami A. Gani dan Zainal Abidin Ahmad, Pendidikan Islam dan Madrasah Hasan al-Banna. Jakarta: Bulan Bintang.

Baheshti, S.M.H. (2002). God in The Quran, terj: Apep Wahyudin, Selangkah Menuju Allah: Penjelasan Al-Qur'an tentang Tuhan. Jakarta: Pustaka Zahra.

Budiman, M. N. (1996). Pendidikan Moral Qur'ani, Strategi Belajar-Mengajar dan Evaluasi pada MAN Se Daerah Istimewa Aceh, Disertasi (Yogyakarta: IAIN Sunan Kalijaga.

Friere, P. (1995). Pendidikan Kaum Tertindas. Jakarta: LP3ES.

H.M. Arifin. (1996). Ilmu Pendidikan Islam. Jakarta: Bumi Aksara.

Langgulung, H. (1985). Pendidikan dan Peradaban Islam. Jakarta: Pustaka alHusna.

Marsiy, M. M. (t.t). At-Tarbiyah al-Islamiyah Ushuluha wa Tathawwuruha $f i$ al-Bilad al-Arabiyah, Kairo: Alam al-Kutub. 
Qothani, M.S. (1994). Memurnikan La’ilaha illa-Allah. (Terj. Abu Fahmi). Jakarta: GIP.

Rahardjo, M. D. (1985). Insan Kamil, Konsepsi Manusia Menurut Islam. Jakarta: Grafiti Pers.

Rais, A. (1989). Cakrawala Islam antara Cita dan Fakta. Bandung: Mizan.

Sabiq, S. (1982). Al-'Aqaid al-Islamiyah, terj.: Moh. Abdai Rathomy, Aqidah Islam Pola hidup manusia beriman. Bandung: Diponegoro.

Shihab, M. Q. (1992). Membumikan Al-Qur'an: Fungsi dan Peranan Wahyu dalam Masyarakat. Bandung: Mizan. Hal. 177-178. Lihat pula, Ahmad Mushthafa al-Maraghiy. Tafsir al-Maraghiy, (Mishr: Mushthafa al-Babiy alHalabiy wa Auladin, 1974).III.

Suryabrata, S. (1990). Psikologi Perkembangan. Yogyakarta: Rake Sarasin. 